\title{
CDH10 wt Allele
}

National Cancer Institute

\section{Source}

National Cancer Institute. CDH10 wt Allele. NCI Thesaurus. Code C143094.

Human CDH10 wild-type allele is located within 5p14.2-p14.1 and is approximately $158 \mathrm{~kb}$ in length. This allele, which encodes cadherin-10 protein, is involved in cell-cell adhesion. Mutations in the gene may be associated with melanoma, pancreatic ductal adenocarcinoma, lung squamous cell carcinoma and colorectal cancer. 